\title{
Advanced Treatment technologies for Poultry Slaughterhouse Wastewater
}

\author{
Phumeza. A. Dyosile, Moses Basitere, Seteno. K.O. Ntwampe
}

\begin{abstract}
Subsequent to the increasing poultry products' demand, the generated large volume of high strength poultry slaughterhouse wastewater, rich in organic compounds, nutrients and solids from the blood, urine, faecal matter and detergents has made treatment prevalent for environmental protection and water sustainability. This paper explores the conducted studies and since adopted technologies for successful treatment of poultry slaughterhouse wastewater: The benefits, deficiencies and remedial systems.
\end{abstract}

Keywords - Anaerobic Digestion (AD), High Rate Anaerobic Bioreactor (HRAB), Up-flow Anaerobic Sludge Blanket (UASB), Static Granular Bed Reactor (SGBR), Poultry Slaughterhouse Wastewater (PSW).

\section{INTRODUCTION}

At 13:58:00, August $26^{\text {th }}$, year 2019 , the world population living in scarce water areas was recorded to be 2326604575 and increasing by the second [1]. At this rate, Guppy and Anderson [2] believe that the global demand is expected to increase with a $50 \%$ margin by the year 2030. The growing scarcity of water around the globe is one of the most pressing worldly concerns that may lead to an international conflict among the nations with transboundary aquifers [2]. This certainty and the advancing industrialization and urbanization leaves the whole world in dire straits as of the $71 \%$ water covering the earth [3], 97\% is saline and of the remaining 3\%, $87 \%$ is in the form of ice [4], thus leaving only $0.3 \%$ potable water which is insufficient for the growing populations and made advancements. For this reason and the continued service to population growth and economic boosting industries such as poultry, that requires large volumes of potable water, continuous

Manuscript received October 10, 2014. This work was supported in part by Cape Peninsula University of Technology (CPUT) under URF RK16 and Bioresource Engineering Research Group (BioERG) under RK45.

P.A. Dyosile is with the Department of Chemical Engineering, Faculty of Engineering and Built Environment, Cape Peninsula University of Technology, P.O. Box 1906, Bellville, South Africa, 7535

Department of Chemical Engineering, Faculty of Engineering and Built Environment, Cape Peninsula University of Technology, P.O. Box 1906, Bellville, South Africa, 7535

Bioresource Research Group, Cape Peninsula University of Technology, P.O. Box 1906, Bellville, South Africa, 7535 improvisation for efficient and successful treatment is necessary to treat the intricate wastewater released.

The variation in the composition of poultry slaughterhouse wastewater lies in the various stages of slaughtering. Whether it is slaughtering, defeathering or cleaning of the facilities or the poultry itself, considerable amounts of high strength wastewater is generated from the set laws such as the South African Meat Safety Act no. 40 of 2000 and Abattoir Hygiene Act no. 121 of 1992, that seek to protect the consumer and hold the abattoirs accountable for quality products are put in place [5]. Due to this, a study performed by Avula et al. [6], showed the average water consumption per bird to be $26.5 \mathrm{~L}$ which means high rate abattoirs roughly produce over two hundred liters per day.

\section{MAterial AND System Design}

Figure 1 below shows the proposed design for treatment of Poultry slaughterhouse wastewater.

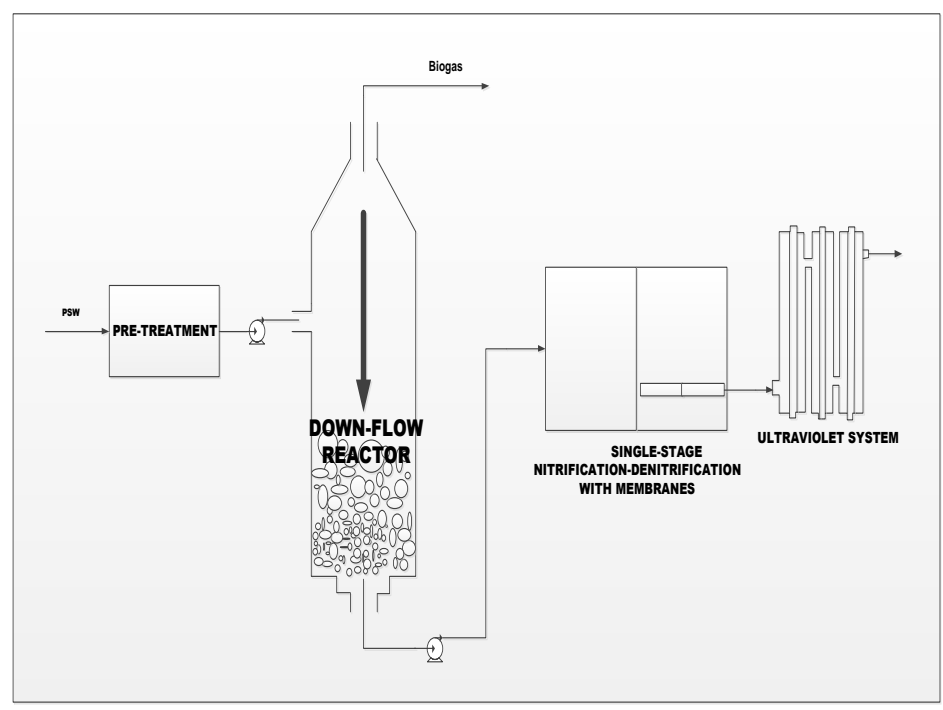

Fig. 1. Poultry slaughterhouse treatment system

The treatment system consists of biological treatment prior the anaerobic digestion process for the purposes of hydrolysis process. As the PSW contains high content of FOG, this stage plays an important role in lowering the organic load of the feed to the anaerobic digestion process, which will assist in 
mitigating deficiencies such as sludge washout in up-flow anaerobic digestion and clogging of the underdrain for the downflow configuration.

The anaerobic digestion effluent is sent to the single stage nitrification and denitrification process for Nitrogen removal. The product of the SND is the further passed through membranes for solids removal and UV system for pathogen removal.

\section{POUltRy SLAUGHTERHOUSE CHARACTERISTICS}

Though the poultry industry has become the confidant in the South African agricultural industry by contributing an approximate amount of $21 \%$ and providing over one hundred thousand jobs [7], through the increased demand, due to affordability and its wide range, the two-edged sector generates a high strength wastewater that contains $35 \%$ more protein and pathogenic microorganisms due to the presence of blood, fat, oil and grease (FOG) in it [8] and an excessive level of nutrients $\left(\mathrm{NH}_{4}{ }^{+}, \mathrm{NO}^{2-}, \mathrm{PO}_{4}{ }^{3-}\right.$ ), organics (COD, BOD, TOC), solids (TDS, TSS, VSS) and change in physical properties which is detrimental to the environment, municipal sewer systems and poses as a human health hazard [5].

Table 1 below, is a representation of typical poultry wastewater characteristics. Reported by Basitere [8].

TABLE I: TYPICAL POULTRY SLAUGHTERHOUSE WASTEWATER CHARACTERISTICS

\begin{tabular}{llll} 
Parameter & Unit & Range & Average \\
\hline Ph & - & $6.5-8$ & 6.88 \\
Alkalinity & $\mathrm{mg} / \mathrm{l}$ & $0-489$ & 489 \\
tCOD & $\mathrm{mg} / \mathrm{l}$ & $2133-10655$ & 6394 \\
sCOD & $\mathrm{mg} / 1$ & $595-1526$ & 974 \\
$\mathrm{BOM}$ & $\mathrm{mg} / \mathrm{l}$ & $1100-2750$ & 1667 \\
$\mathrm{TKN}$ & $\mathrm{mg} / 1$ & $77-352$ & 211 \\
$\mathrm{TP}$ & $\mathrm{mg} / \mathrm{l}$ & $8-27$ & 17 \\
FOG & $\mathrm{mg} / \mathrm{l}$ & $131-684$ & 406 \\
$\mathrm{TDS}$ & $\mathrm{mg} / \mathrm{l}$ & $372-936$ & 654 \\
$\mathrm{TSS}$ & $\mathrm{mg} / \mathrm{l}$ & $315-1273$ & 794 \\
VSS & $\mathrm{mg} / 1$ & $275-1200$ & 738 \\
\hline \hline
\end{tabular}

\section{A. General Limit for Effluent Discharge}

Over the past decade, the growth of the poultry industry has made it the biggest segment on the AgriEconomy in South Africa [9]. The benefits of the industry include the wide range of products produced from a single bird that works to suit the individual budgets of all South Africans, such as the chicken feet, heads and offal (Liver, gizzard, heart). During the slaughtering and sorting process, the high rates create a large room for contamination of the meat and poses a risk in environmental hygiene and food safety [5], hence the use of large volumes of high-pressured potable water, to ease the anxious consumers. However, as mentioned above, the generated wastewater contains unwanted constituents which may culminate into eutrophication and deoxygenating of freshwater bodies [8], [10].

Table 2 below shows standards for effluent discharge into sewage systems in South Africa. To bridge the gap and meet the general limit of effluent discharge, development projects have been done to successfully treat and potentially alleviate current water challenges.

TABLE II: GENERAL LIMIT FOR EFFLUENT DISCHARGE

\begin{tabular}{llll}
\hline Parameter & & World & South \\
& Unit & $\begin{array}{l}\text { Bank } \\
\text { Standards }\end{array}$ & $\begin{array}{l}\text { African } \\
\text { Standards }\end{array}$ \\
\hline Faecal Coliforms & $\begin{array}{l}\text { Per } \\
100 \mathrm{ml}\end{array}$ & - & 1000 \\
COD & $\mathrm{mg} / 1$ & 250 & 75 \\
pH & & $6-9$ & $5.5-9.5$ \\
Ammonia & $\mathrm{mg} / 1$ & 10 & 6 \\
Nitrates & $\mathrm{mg} / 1$ & 10 & 15 \\
Chlorine & $\mathrm{mg} / 1$ & - & 0.25 \\
Suspended Solids & $\mathrm{mg} / 1$ & 50 & 25 \\
Soap, Oil and Grease & $\mathrm{mg} / \mathrm{l}$ & 10 & 2.5 \\
\hline \hline
\end{tabular}

\section{DISCUSSION}

\section{A. Poultry slaughterhouse wastewater treatment system trail}

There have been numerous treatment technologies used for high strength PSW treatment, both aerobic and anaerobic. The use of aerobic treatment systems (ATD) require a large volume of oxygen to oxidize the biomass, thus making it an expensive treatment method. In comparison to anaerobic digestion, the operating costs are high and the generated sludge requires further dewatering [12]

\section{B. Anaerobic Digestion}

The anaerobic digestion (AD), which uses bacteria as a subjugator for the present organics and has been found as ideal treatment technology for FOGs and high concentration particulate removal [12]. In these types of biological reactors, in the absence of oxygen, at mesophilic temperature range (30-40 ${ }^{\circ} \mathrm{C}$ ) and a $\mathrm{pH}$ range of 6.5-9 [12], microbial interaction takes place. It therefore results in a treated effluent with $\pm 90 \%$ treatment efficiency [10], [13] and by-products such as biogas, 
bio-sludge, ammonium $\mathrm{NH}_{4}{ }^{+}$and phosphate $\mathrm{PO}_{4}{ }^{3-}$ compounds [12].

\section{Microbial Interaction in Anaerobic Digestors}

After reactor acclimation and microbial maturation, the PSW introduced into the reactor is broken down into soluble compounds in a process called Hydrolysis [8], [14]. Subsequently, these compounds are transformed by the fermentative bacteria resulting in alcohol, and unstable volatile acids in Acidogenesis [12], [15]. Following Acidogenesis, in Acetogenesis, the volatile acids break, due to instability, to form acetate, carbon dioxide and hydrogen [8], [14]. Lastly, in the presence of carbon dioxide, acetoclastic methanogens grow and result in the conversion of acetate to methane in a process called Methanogenesis [8], [14].

\section{High Rate Anaerobic Bioreactor}

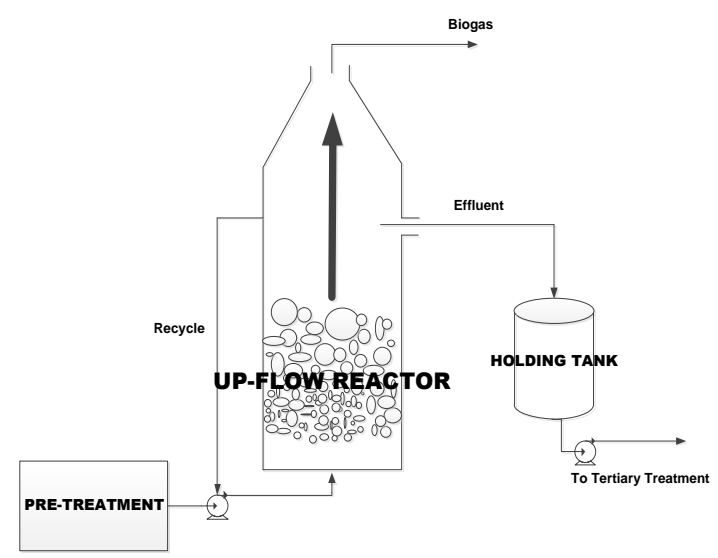

Fig. 2. Up-flow configurated reactor

The Up-flow Anaerobic Sludge Blanket (UASB) is anaerobic digestion treatment technology, where wastewater enters at the bottom of the reactor and treated through the sludge blanket made of microbial granules [16] after which the Expanded Granular Bed Reactor (EGSB) was developed with the same working principle but an additional recycle stream. These reactors alone have a working efficiency of up to $90 \%$ of COD and have an ability to withstand high level of organics [16]. However, the success of these reactors relies on the gas-liquid-solid separation system [17], [18]. From studies conducted, Njoya et al. [19] noted that up-flow configurated reactors run the risk of sludge washout, resulting in the loss of the microorganisms which further results in increased solid concentration in the effluent and reduced quality of treatment [18].

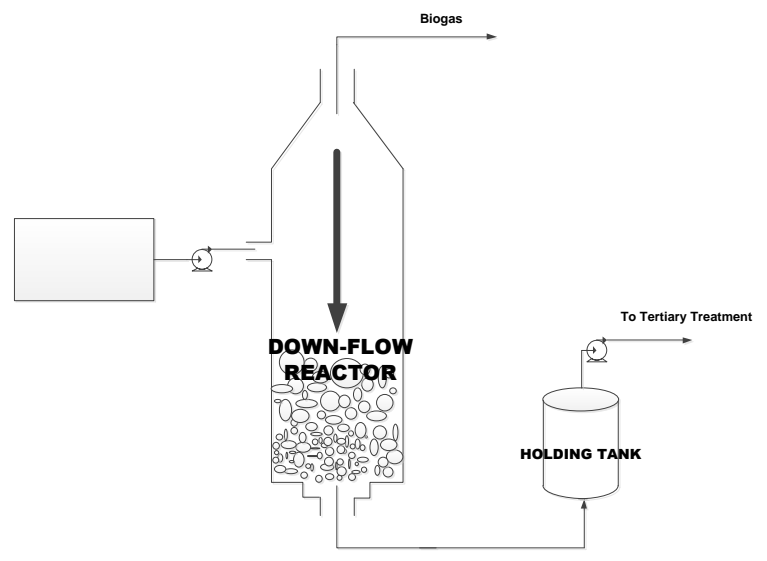

Fig. 3. Down flow configurated reactor

The static granular bed reactor (SGBR), an invention of Ellis from Iowa State University in the year 2000 [20] receives wastewater from the top and the effluent at the bottom of the reactor. From this configuration, the gas-liquid-solid separation stage is unnecessary [18], [19] as the produced biogas bubbles to the top while the gravity acts on the water [18] and present solids and particulates which, overtime, compact on the bed and may lead to reactor clogging [8]. The SGBR has been proven to produce a higher quality effluent than that of the up-flow reactor with COD removal greater than $90 \%$ [15].

\section{E. Anaerobic Treatment technologies performances}

Treatment technologies under the anaerobic digestion include reactors such as Up-flow Anaerobic Sludge Blanket (UASB), Expanded Granular Sludge Bed (EGSB) and Static Granular Bed Reactor (SGBR) each developed from performance evaluations on wastewater treatment.

The UASB, was created in the 1970's as a substitution to the septic tank [27]. As the name suggests, the reactor has an upward configuration that allows the created biogas to mix with the water and the FOG present in the PSW to attach to the granular sludge, thus resulting in the risk of sludge washout [12]. In study conducted by Saghir and Hajjar [28], for the treatment of poultry slaughterhouse wastewater, the reactor achieved its best COD removal of $83 \%$ at hydraulic retention time of 36 hours.

The EGSB is an up-flow velocity derivative of the UASB [27], created in Netherlands in the 1980s to remedy the short coming evident in the UASB [29]. However, along with the UASB, the EGSB's disadvantage includes the additional gas-liquid-solid separation stage, extra energy to overcome gravitational forces [30] and the increased risk of sludge washout, further leading to reduced efficiency [31].

The SGBR, an invention of Ellis [20] is a down flow configured reactor that is an advancement from the up-flow. The configuration requires less steps than the up-flow, less energy, and has a benefit of sludge retention ([18], [19]. However, when wastewater contains high total suspended solid and FOG 
concentration, the reactor is prone to clogging of the underdrain due to the use of pea gravel at the bottom of the reactor.

TABLE III: COD AND TSS REMOVAL EFFICIENCIES

\begin{tabular}{lll}
\hline \hline & COD Removal $(\%)$ & TSS Removal $(\%)$ \\
\hline UASB & $>90$ & \\
EGSB & $\approx 67 \%$ & $\approx 83 \%$ \\
SGBR & $<90$ & $95 \%$ \\
\hline \hline
\end{tabular}

In summary, with regards to the Table 3, drawn from studies by Rinquest [10], Basitere et al. [32] \& Tilley et al. [16], the SGBR has shown a level of superiority over the other reactors. However, it runs a risk of clogging which can impede the entire system performance. In a study done by Basitere et al., [25] Exploring the Treatment of Poultry Slaughterhouse Wastewater Using Static Granular Reactor Coupled with UF membrane over a 9 week period, from the reactor performance of $93 \%$ and $95 \%$ COD and TSS removal, with the additional of the UF membranes, the system achieved $98 \%$ and $99.8 \%$ COD and TSS removal respectively. However, Basitere et al. [28] noted that compared to a SGBR study conducted in the year 2008 by Evans [18], the reactor performance reached $95.7 \%$ suggesting an error in the system which maybe a resulted of a solid build up in the granules or an influence of the organic loading rates. For remedial effect;

a. The addition of a pre-treatment may alleviate clogging and potentially reduce shock loading by reducing the FOG, suspended solids and surface tension in the PSW using the grown facultative microbes as a primary treatment prior to biological treatment. This is also improving the known clogging and fouling of membranes.

b. The addition of a recycle to periodically wake the sludge, thus resulting in a hybrid-SGBR may significantly reduce clogging, correct the little error possible in the reactor.

Though, overall, these high rate anaerobic reactors produce good quality effluents from the high strength poultry wastewater, the advancing requirements for effluent discharge care for produced by-products $\left(\mathrm{NH}^{4+}, \mathrm{PO}_{4}{ }^{3-}\right)$ as well, listed in the general limit for effluent discharge section, necessitating the need for tertiary treatments to improve the quality and remedy deficiencies not accomplished by the bioreactor. These include nutrient removal by single-stage nitrification-denitrification, particulates and pathogens by membranes.

Part of the disadvantages of anaerobic digestion, is its inability to remove maximal nitrogen. For curation, the single-stage nitrification-denitrification is used. However, prior nitrification and denitrification, ammonification takes place in the anaerobic reactor during hydrolysis where organic nitrogen is converted to ammonia [21]. The two equations below signify the nitrification process which begins in an aerated environment, where the Nitrosomonas bacteria converts ammonia and ammonium to nitrite at high retention times [10]. A study by Rinquest $e t$ al.
[22] showed that increased retention times resulted in an optimum TN removal that increased TN removal from 33\% to $79 \%$.

$$
2 \mathrm{NH}_{3}+7 / 2 \mathrm{O}_{2} \rightarrow 2 \mathrm{NO}_{2}+2 \mathrm{H}_{2} \mathrm{O}+2 \mathrm{H}^{+}[14](1)
$$

Followed by the conversion of nitrite to nitrate due to the nitrobacteria [10], [14].

$$
\mathrm{NO}_{2} \stackrel{\text { Oxygen Environ: }}{\longrightarrow} \mathrm{NO}_{3}^{-}(2)
$$

In denitrification, the nitrates are reduced to nitrogen gas [23]. Reaction requirements include; a sufficient carbon source, heterotrophic bacteria and an anoxic environment [10]; [23].

Combined SND reaction: $\mathrm{NH}_{4}^{+} \rightarrow \mathrm{NH}_{2} \mathrm{OH} \rightarrow \mathrm{N}_{2} \mathrm{O} \rightarrow \mathrm{N}_{2}$ [14] (3)

Pochana and Keller [23] proved for a 95\% total nitrogen removal, The ratio 5:20 TOD:TKN for denitrification, dissolved oxygen concentration lesser that $0.2 \mathrm{mg} / \mathrm{l}$ for denitrification and higher than $0.5 \mathrm{mg} / \mathrm{l}$ nitrification is necessary.

From the large range of membranes, classified by pore size, shape, material of construction or configuration, the selection is crucial depending on the wastewater to be treated. Similarly, for the treatment of high strength PSW multiple studies focus on the treatment using ultrafiltration with a pore size ranging from 0.002-0.1 microns which intern forms a barrier against pathogens and bacteria [24].

According to a study by Malmali et al. [24], can offer absolute barriers to pathogens and in terms of COD, TSS and FOG reduction, Basitere et al. [25] found average removal of $64 \%$, $88 \%$ and $48 \%$ respectively which assisted in achieving a total of $98 \%, 99.8 \%$ and $92.4 \%$. Its known advantages also include:

a) Simplicity

b) No chemicals required

c) Compactness

d) Cost Efficiency

To counter the permeation of pathogenic microorganisms due to unnoticed membrane fouling, the ultraviolet is an effective disinfecting method that exposes to the bacteria to a UV radiation via lamps [24].

The pathogenic microbes namely; coliforms and e-coli present as a result of blood and faecal matter traces present in the poultry slaughterhouse wastewater are reduced to \pm 6 CFU/100mg and 0 CFU/ 100mg which far exceeds the set South African general limit for effluent discharge [26].

However, to achieve success in the secondary and tertiary stages and reduce the strain on SGBR, SND and Membrane operation offered by the fatty and nutrient rich nature of PSW, biological pretreatment has been found as an effective method after screening. The combination of the pre-treatment that uses facultative microbes to reduce the hardwater and UV lamps on the hybrid-SGBR (with recycle), single-stage nitrification-denitrification and membranes will make of an efficiently running plant that produces an effluent reduced not only of organics, solids and nutrients but pathogens as well. 


\section{CONCLUSION AND RECOMMENDATIONS}

The SGBR bioreactor, SND and UF membrane combination is a treatment combination which has been found effective. However, the poultry slaughterhouse wastewater highly contributes to bioreactor clogging and membrane fouling. The addition of the pre-treatment will release to the reactor an effluent that is healed of the heavy FOG, particulate and suspended solids that tend to clog the reactor and membranes. In the case of bed awakening, the additional recycle will periodically activate the bed, keeping the system and lessen the clogging tendency of the reactor.

As a last step, the UV lamps will safely rid the water of pathogenic microorganisms thus finally producing a quality effluent that far exceeds the set South African standards for general limit.

\section{REFERENCES}

[1] "World Population Living in Scarce Water Areas," World Data Lab, 2019. [Online]. Available: https://worlddata.io/. [Accessed: 26-Aug-2019].

[2] L. Guppy and K. Anderson, "Global Water Crisis: the Facts," no. September 2017, pp. 1-3, 2017.

[3] M. Williams, "What Percent Of Earth is Water?," 23 April, no. 2, December, p. 1, 2014.

[4] J. Wun, Industrial Wastewater Treatment. London: Imperial College Press, 2006.

[5] N. A. Molapo, "Waste Handling Practices in the South African High-Throughput Poultry Abattoirs," CENTRAL UNIVERSITY OF TECHNOLOGY, FREE STATE, 2009.

[6] R. Y. Avula, H. M. Nelson, and R. K. Singh, "Recycling of poultry process wastewater by ultrafiltration," Innov. Food Sci. Emerg. Technol., vol. 10 , no. 1 , pp. $1-8,2009$. https://doi.org/10.1016/j.ifset.2008.08.005

[7] AgriSETA, "Authorisation and Official Sign-Off," 2017.

[8] M. Basitere, "Performance Evaluation of An Up- and Down-Flow Anaerobic Reactor for The Treatment of Poultry Slaughterhouse Wastewater in South Africa," CapePeninsula University of Technology, 2017.

[9] Fairplay, "Overview of the South African poultry industry - Fairplay: Stop Trade Dumping Now," 2018. [Online]. Available: https://fairplaymovement.org/overview-of-the-south-african-poultry-ind ustry/. [Accessed: 05-Oct-2019].

[10] Z. Rinquest, "Poultry Slaughterhouse Wastewater Treatment Using a Static Granular Bed Reactor (Sgbr) Coupled With a Hybrid Sidestream Membrane Bioreactor," no. December, 2017.

[11] R. Hirji, Rafik; Davis, "Water quality: assessment and protection," Water Resour. Environ. Tech. Note D.1, no. March, pp. 1-36, 2003.

[12] M. Njoya, M. Basitere, and S. K. O. Ntwampe, "High Rate Anaerobic Treatment of Poultry Slaughterhouse Wastewater (PSW)," in New Horizons in Wastewaters Management, E. Fosso-Kankeu, Ed. Nova Science Publishers, Inc., 2019, p. 38.

[13] E. Debik and T. Coskun, "Use of the Static Granular Bed Reactor (SGBR) with anaerobic sludge to treat poultry slaughterhouse wastewater and kinetic modeling," Bioresour. Technol., vol. 100, no. 11, pp. 2777-2782, 2009. https://doi.org/10.1016/j.biortech.2008.12.058

[14] M. H. Geradi, The Microbiology of Anaerobic Digesters. New Jersey: John Wiley \& Sons, Inc, 2003.

[15] K. M. Evans, "Fundamentals of the Static Granular Bed Reactor," Iowa State University, 2004.

[16] E. Tilley, L. Ulrich, C. Lüthi, P. Reymond, and C. Zurbrügg, Compendium of Sanitation Systems and Technologies. 2nd Revised Edition. Swiss Federal Institute of Aquatic Science and Technology (Eawag), 2014

[17] Y. Williams, "Treatment of Poultry Slaughterhouse Wastewater Using An Expanded Granular Sludge Bed Anaerobic Digester Coupled with Anoxic/Aerobic Hybrid Side Stream Ultrafiltration Membrane
Bioreactor," no. December, 2017

[18] T. G. Ellis and K. M. Evans, "A new high rate anaerobic technology, the static granular bed reactor (SGBR), for renewable energy production from medium strength waste streams," WIT Trans. Ecol. Environ., vol. 109, pp. $141-150,2008$. https://doi.org/10.2495/WM080161

[19] M. Njoya, M. Basitere, and S. K. O. Ntwampe, "Treatment of poultry slaughterhouse wastewater using a down-flow expanded granular bed reactor," Water Pract. Technol., pp. 1-15, 2019. https://doi.org/10.2166/wpt.2019.039

[20] T. Ellis and K. Mach, "Static Granular Bed Reactor," US 6,709,591 B1, 2004

[21] J. C. Akunna, C. Bizeau, and R. Moletta, "Nitrate reduction by anaerobic sludge using glucose at various nitrate concentrations: Ammonification, denitrification and methanogenic activities," Environ. Technol., vol. 15, no. 1, pp. 41-49, 1994 https://doi.org/10.1080/09593339409385402

[22] Z. Rinquest, M. Basitere, S. K. O. Ntwampe, and M. Njoya, "Poultry slaughterhouse wastewater treatment using a static granular bed reactor coupled with single stage nitrification-denitrification and ultrafiltration systems," J. Water Process Eng., vol. 29, no. January, 2019. https://doi.org/10.1080/09593339409385402

[23] K. Pochana and J. Keller, "Study of factors affecting simultaneous nitrification and denitrification (SND)," Water Sci. Technol., vol. 39, no. 6, pp. 61-68, 1999.

https://doi.org/10.1080/09593339409385402

[24] M. Malmali, J. Askegaard, K. Sardari, S. Eswaranandam, A. Sengupta, and S. R. Wickramasinghe, "Evaluation of ultrafiltration membranes for treating poultry processing wastewater," J. Water Process Eng., vol. 22, no. March, pp. 218-226, 2018. https://doi.org/10.1080/09593339409385402

[25] M. Basitere, Z. Rinquest, M. Njoya, M. S. Sheldon, and S. K. O. Ntwampe, "Treatment of Poultry Slaughterhouse Wastewater Using Static Granular Reactor Coupled with UF membrane," IWA Publ., pp. $1-9,2017$. https://doi.org/10.1080/09593339409385402

[26] I. R. De Nardi, V. Del Nery, A. K. B. Amorim, N. G. dos Santos, and F. Chimenes, "Performances of SBR, chemical-DAF and UV disinfection for poultry slaughterhouse wastewater reclamation," Desalination, vol. 269 , no. 1-3, pp. 184-189, 2011 https://doi.org/10.1080/09593339409385402

[27] S. J. Lim, "Comparisons Between the UASB and the EGSB Reactor," Iowa State, 2009.

[28] A. saghir and S. Hajjar, "The treatment of Slaughterhouses wastewater by An Up Flow - Anaerobic Sludge Blanket (UASB) reactor.," Sak. Univ. J. Sci., vol. 22, no. 5, pp. 1-1, 2018.

https://doi.org/10.1080/09593339409385402

[29] R. Cruz, Salomon; Valdovinos, Rios; Albores, Pola; Rivera, Lagunas; Gordillo, Meza; Valdiviezo, "Expanded granular sludge bed bioreactor in wastewater treatment," vol. 5, no. 1, pp. 119-138, 2019.

[30] W. Practice, M. Basitere, M. Njoya, Z. Rinquest, and S. K. O. Ntwampe, "Performance evaluation and kinetic parameter analysis for static granular bed reactor (SGBR) for treating poultry slaughterhouse wastewater at mesophilic condition," no. June, 2019. https://doi.org/10.1080/09593339409385402

[31] M. Basitere, Y. Williams, M. S. Sheldon, S. K. O. Ntwampe, and D. De Jager, "Performance of an expanded granular sludge bed (EGSB ) reactor coupled with anoxic and aerobic bioreactors for treating poultry slaughterhouse wastewater," vol. 11, no. 1, pp. 86-92, 2016. https://doi.org/10.1080/09593339409385402

[32] M. Basitere, Y. Williams, M. S. Sheldon, S. K. O. Ntwampe, D. De Jager, and C. Dlangamandla, "Performance of an expanded granular sludge bed (EGSB) reactor coupled with anoxic and aerobic bioreactors for treating poultry slaughterhouse wastewater," Water Pract. Technol., vol. 11, no. 1, pp. 86-92, 2016 https://doi.org/10.1080/09593339409385402 


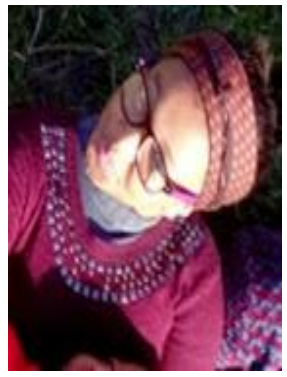

Phumeza A. Dyosile is a master's candidate at the Cape Peninsula University of Technology. The author's highest qualification is a Baccalaureus Technologiae (Btech) in Chemical Engineering. She obtained the degree in 2018 at Cape Peninsula University of Technology, Cape Town, South Africa. Originally, she is from East London, Eastern Cape where she was born in the year 1995 on the $28^{\text {th }}$ of April and attended high school at Port Rex Technocal High School.

She is currently working on a poultry slaughterhouse wastewater treatment project under the lead of M. Basitere and S.K.O Ntwampe at the Cape Peninsula University of Technology, Chemical Engineering Department, Bellville Campus. 